\title{
The Application of Composite Materials in Contemporary Jewelry Teaching
}

\author{
Xiao-Yan ZHANG* \\ Department of Fashion, Shanghai University of Engineering Science, 201620, China
}

\begin{abstract}
With the collision and blending in area of the design, more and more mixed media are used in modern jewelry, the understanding of people for the material no longer stay in the narrow space of the past. Contemporary jewelry design began paying attention to new visual sense of mixed materials. The designer is used to putting the material as a carrier of design concepts. and see it as a kind of media which can construct a bridge between the viewers, wearers and designers. As a form of freedom, it is a mixture of a variety of materials in the field of contemporary jewelry. Mixed media Jewelry has developed quite mature in foreign jewelry circle. It is just get the favor of consumers at home. Composite material is more widely applied in jewelry works in the teaching.
\end{abstract}

KEYWORD: Composite materials; jewelry teaching; mixed media; jewelry design

\section{INTRODUCTION}

In Europe and the United States, more and more graduate students of jewelry design major set up personal studio after graduation, and in their studio engaged in the design and manufacture of mixed media jewelry. Among them there are many famous designers such as Tabea reulecke, Suzanne Smith, Ramon puig cuyas, Polly wales etc. At home, mixed media jewelry open market in recent years, In Shanghai art gallery and salon, we can watch some jewelry with special composite material such as butterfly wings, fibers silica gel, animal skins, the new paper, etc. These jewelry works have exquisite workmanship and visual sense art. They pay more attention to forms of aesthetic feeling, design concept and the designer's individuality. Their material is different from expensive fine jewelry which pay more attention to the artistic quality and inner spiritual value, these jewelry works slowly walked into the heart of people with its creation story. Mixed media jewelry, as it were, as a new creative expressing form of jewelry, get the more increasing attention by domestic jewelry designers and consumers.

\footnotetext{
* Xiao-Yan Zhang.

Shanghai University of Engineering Science. Associate professor. Master.

Graduate school: Beijing institute of fashion technology.

Main research direction: modern jewelry design and predution.
}

\section{THE PROSPECT OF MIXED MEDIA JEWELRY DESIGN}

With the pace of life accelerating and consumption levels continuing to improve, people pay more and more attention to spiritual sphere. In the aesthetic aspects of jewelry consumers constantly in pursuit of individuality and unique. Some of the precious metals, diamonds and precious stones are not the only object. They are replaced by some mixed media jewelry which is becoming popular. Personalized, odd characteristic and wearing effect of jewelry become the focus of modern value. Some jewelry work that is concise, abstract, threedimensional, instead of the usual tedious, complicated and exquisite traditional jewelry, attract more attention. At the same time, people's needs for jewelry spirit make it no longer stay in the level of jewelry accessories. It has become a carrier of the consumer' self-expression. Mixed media jewelry become one branch of the most timely jewelry field with the diversity of its material, creative forms of freedom, the uniqueness of emotional appeal, the uniqueness of the wear effect. Just like telling a story, mixed media jewelry works become unique carrier for designers to express inner feeling and communicate with the outside world. 


\section{THE DIVERSITY OF MATERIALS FOR MIXED MEDIA JEWELRY DESIGN}

The material of mixed media jewelry determines the side of modern, fashion, art in work. It is different from traditional jewelry in form of oneness, unlike traditional jewelry also to more pursue the material value. One important characteristic of mixed media jewelry is that its connotation is expressed by different materials, and even some strange unusual material or existing objects can impress people. The following work is one pair of earrings made of butterfly specimens and organic glass. Designers use organic glass clamping butterfly specimens in the middle, the two pieces of organic glass riveted together in the riveting process. Simple technology and natural color display personality aspect of the works.

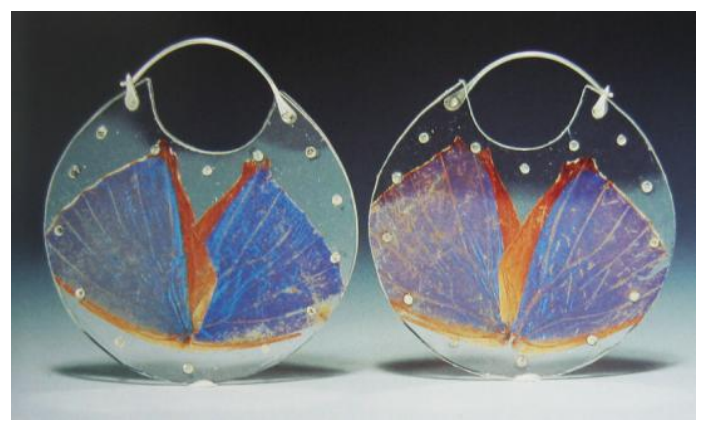

Picture 1: Luana Coonen's mixed media earrings work

Different from traditional jewelry materials of oneness, mixed media jewelry use ceramics, wood, shells, coral, enamel, plastics, leather and other wider material such as paper. They show unique personalized side of the contemporary jewelry with artistic exaggeration and deformation. To a certain extent, it transcended the traditional decorative areas, often showing one certain cultural taste of the designer or the wearer and people's attitude to life, which is similar to contemporary art.

The mainstream materials of jewelry design is still gold, silver, other precious metals and gemstones, but with the development of society, the meaning about jewelry design has shifted from jewelry itself to relationship between itself and people. When you want to show the wearer's style, to convey the wearer and the designer's ideas and to express a feeling or thought, traditional materials has been unable to meet the needs of contemporary jewelry designs. A lot of new material is used in the design, and gives a new meaning and form of jewelry. In some galleries and contemporary jewelery exhibition, we can see, lots of materials has been used in jewelry creation such as "fiber, glass, plastic, ceramic, silicone, silk, foam, paper, alloy, stainless steel, resin, rubber, and even flowers and trees, etc.". With the unlimited expansion of jewelry materials's scope, as long as the design concept needs, almost all of the material in nature can be used in the design. Some non-precious metals such as titanium, stainless steel, aluminum began to be loved by designers.

\section{UNIQUENESS OF THE CONCEPT AND EMOTIONAL APPEAL FOR MIXED MEDIA JEWELRY}

Rather than the concept expression of mixed media jewelry works more personalized, better to say the concept expression and emotional appeal of mixed media jewelry works have uniqueness. The process that the creator creates jewelry is just like to tell a moving story deeped in his heart. this is not to say that designers creat a work like telling a story, but to express the story with the creation of forms.

The work "streamer" is from Zhang Yi-lei who is one student in shanghai university of engineering science garments college. Designer's inspiration come from the ancient poetry "A Spray of Plum Blossoms, The ship passed through Wujiang", in the words, "The person is easy to grow old in the light, as time goes by, cherry red, green banana......". As an aesthetic subject, the designer is enlightened by the passing of time, transmigration of all things on earth. just like "fleeting time, white clouds change into grey dogs." The work expressed "fickle things, people are fickle" by tree shape and constantly changing background. The dark shadows through the streamer sway the minds of the designers, like an ethereal distant dream. This mood of reverie full of passion is caused by the creation of the designer. The creative passion of designer was triggered by artistic conception.

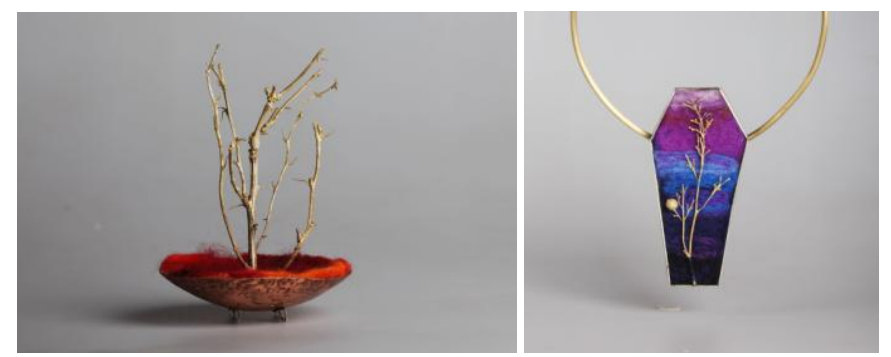

Picture2, 3: Name of the works: streamer. Designer: Zhang Yilei.

Guidance teachers: Zhang xiao-yan, Wang shu- li. Photography: Zhou zhi-peng

shanghai university of engineering science garments college

Material and process: copper forging, casting branch, felt

Jewelry designer must give full consideration to the artistic and emotional of jewelry, and put the emotional design into jewelry creation, only in this way, we can create exciting works. Emotional design animate the work, modern jewelry designers especially lay emphasis on the concept of jewelry creativity. This kind of method of concept creation 
has become silent bridge and communication media between consumers and designers. Instead of saying that people buy a piece of jewelry or art or fashion appearance, much better to say this piece of jewelry's emotions touched the hearts of consumers. For the jewelry artist itself, in most cases, this kind of emotion is often their first creative motivation.

\section{SPACE AND FORM BEAUTY OF THE MIXED MEDIA JEWELRY}

When students have a preliminary idea of creative works, teacher often instructs them to sketch or make a test piece in accordance with their own ideas. Of course, this process is not absolute, some students first find interesting material, try to do test piece according to the material, other students who have a first draft and then look for material according to sketch, then make test artifacts to the final works. According to the teaching practice, we find that a lots of students do not know how to start in the sketch phase, and there are even some students coming back to finish the works painted renderings. When students have an idea, we can encourage him to think from jewelry space beauty, looking for inspiration from architectural art, and learning the method of concept expression and visual modeling technique, applying it to their jewelry works.

Composite materials is the result of an idea. Sometimes we consider the material as a starting point, and not the material itself, it have been more than material, for example, raw wood. Designers are always looking for something which can best express the idea of material. Most of the time, one mixture of several material is often the best solution, because their contrast can create some design tension, or their mixture can enhance sense of form. This point architectural art same to jewelry art.
The following jewelry works "The sea. the Sound" is an student's work who named Ma xiao-xi, The designer said," "conch like gift from the sea, beautiful and mysterious, from ancient to modern times, recorded hundreds of millions of years, the hundreds of millions of years possessed in the conch, when we took the conch on the ears, we can hear the voice come from millions of years ago, from ancient to now .I am feeling it full of spirituality. I chooses the conch and pointed conch as main material, has designed a series of fashion jewelry. I hope more people can hear it from the sound of the sea, mysterious, nature, and full of flexibility.
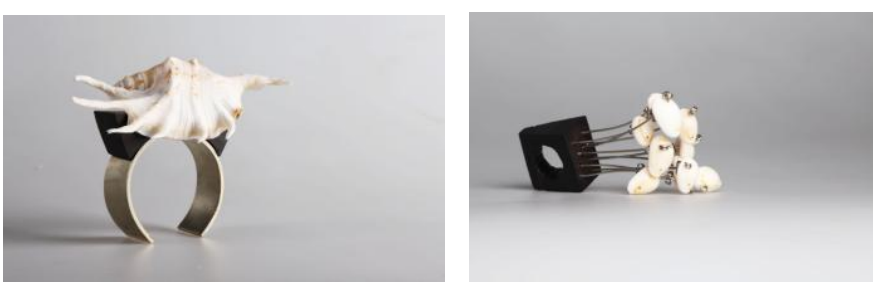

Picture4, 5: Name of the works: The sea. the sound. Designer: Ma xiao-xi..

Guidance teachers: Zhang xiao-yan. Photography: Zhou zhipeng

shanghai university of engineering science garments college Material and process: ebony, conch, white wire, forging and riveting process

\section{REFERENCES}

[1] Suzanne Tennenbaum, The Jeweled Garden. London: Thames and Hudson, 2006.

[2] Jones, Sue Jenkyn, Fashion design. London: Baker \& Tayl, 2005.

[3] Peter Lane, Contemporary Studio Porcelane. London: A \&C Black, 2005.

[4] Deborah Nadoolman,Costume design. Burlington: Focal Press, 2007.

[5] Terry Taylor, The Art of Jewelry: Wood: Techniques,, Projects, Inspiration(Art of Jewelry). Lark Books, 2008. 